\title{
Determinants of Students' Observance of Library Regulations in Federal Polytechnic Nekede, Owerri, Imo State, Nigeria
}

\author{
Adaora J. Udo-Anyanwu1, Matilda C. Oduagwu², Nkechi 0. Okorie1 \\ ${ }^{1}$ Department of Library and Information Science, Imo State University, Owerri, Nigeria \\ ${ }^{2}$ Library Division, Federal Polytechnic Nekede, Owerri, Nigeria \\ Email: adaoraudoanyanwu@yahoo.com, oduagwumatilda@gmail.com, onkechi17@yahoo.com
}

Received 26 March 2015; accepted 11 April 2015; published 16 April 2015

Copyright (C) 2015 by authors and OALib.

This work is licensed under the Creative Commons Attribution International License (CC BY).

http://creativecommons.org/licenses/by/4.0/

(c) $\underset{\mathrm{EY}}{\mathrm{P}}$ Open Access

\begin{abstract}
This paper studied the determinants of students' observance of library regulations in Federal Polytechnic Nekede, Owerri. The survey design was used. The population of the study consisted of all the 400 registered users of the library from which a sample of $\mathbf{1 9 6}$ was drawn. The questionnaire structured using the 4-point scale was the major research instrument. The data collected were analyzed using the mean rating scale and 2.50 was the cut-off point. The findings showed that 5 out of the 6 determinants stated by the researchers, namely, user education, availability of information resources, staff attitude, disciplinary measures and security measures have influence on students' observance of library regulations while operating hours as a determinant does not have influence on students' observance of library regulations. Based on the findings, the study recommended that the determinants that encourage observance of library regulations should be continued and improved with electronic monitor added to the other security measures.
\end{abstract}

\section{Keywords}

Staff Attitude, Operating Hours, User Education, Security Measures, Disciplinary Measures, Availability of Information Resources

Subject Areas: Library, Intelligence and Philology

\section{Introduction}

The focus of any academic library is to collect, organize, preserve and provide access to knowledge and information. Like any human establishment, there are rules and regulations guiding the use of the library irrespective of the type. These regulations cover access, use of facilities, loans, fees and charges. It is important for readers 
to be familiar with these rules to avoid falling victims or violate any of them. Based on this, Alokun (2004) [1] points out that readers are therefore, required to behave well in the library. A study on observance of library regulations cannot be complete without making mention of the library use by students. This is so because it is in the course of using the library that students are expected to observe the regulations. Williams in Whitemire (2001) [2] defines library use as using study areas, using photocopiers, borrowing books, reading periodicals, asking for staff assistance, and using reserve collections.

Library services can only be achieved through the availability of library collections. The unavailability of library materials in large quantity in some libraries has been seen to contribute to the disappearance of materials in libraries and hiding of library materials. Library orientation and instruction are among the programmes used to enhance library skills to new students. These programmes help students to know the various types of library resources, services and the rules and regulations guiding library use. For students to observe library regulations, they must be made to know them. One of the ways of doing this is through user education. Aguolu and Aguolu (2002) [3] state that, one of the benefits of user education is that it enables the users to be introduced to the rules and regulations governing their conduct in library use.

The length of time that libraries open determines the usage of the library materials and thus indirectly determines the degree of observance of library regulations. Libraries devise disciplinary measures to deter students from non-observance or punish students who default. These disciplinary measures include payment of fines, replacement of the information materials or double pay for lost books, withdrawal of library card and expulsion. Libraries adopt various measures to ensure the security of materials. Restriction of entry into the library with briefcases, bags, regular patrol by library staff, checking of patrons going out at the exit are some of the security measures used.

Unless the issue of observance is looked into, academic libraries are bound to loose their importance as regards the provision of effective library services. It is against this background that this study is being carried out. However, the study will only be limited to library-related factors.

\section{Statement of the Problem}

Libraries have regulations which guide their users. These regulations are meant to be adhered so strictly to ensure that library staffs perform their services effectively and users make adequate use of the library. It is however disheartening to note that students in tertiary institutions appear not to observe these regulations strictly. The non-observance of these regulations has led to the library not performing its roles effectively in terms of provision of information and services. Could the observance or non-observance of these library regulations be attributed to these determinants? This is the gap in knowledge that needs to be filled. Knowledge of these determinants would contribute significantly to our knowledge.

This study therefore seeks to examine the influence of these library-related determinants on the observance of library regulations by students of Federal Polytechnic Nekede, Owerri, Imo State, Nigeria.

\section{Research Questions}

The following research questions were answered by this study:

1) What is the influence of user education on students' observance of library regulations?

2) What is the influence of availability of information resources on students' observance of library regulations?

3) What is the influence of staff attitudes on students' observance of library regulations?

4) What is the influence of user operating hours on student' observance of library regulations?

5) What is the influence of disciplinary measures on students' observance of library regulations?

6) What is the influence of security measures on students' observance of library regulations?

\section{Review of Related Literature}

Observance is an act or practice of complying with a law, custom, command or rule. The non-observance of library regulations by students lead to delinquency which according to Broadhead (2002) [4] is defined as an action that is illegal or immoral which adversely affects library services. Such actions include unruly behaviours, receiving phone calls in the library while others are theft and mutilation of library materials, impersonation, misuse of catalogue (manual or OPAC), and computer system, refusing to return overdue books, etc. 
Nina-Okpousung (2011) [5] recommends that the library management should ensure that every academic year, libraries offer series of library orientation courses on library use, rules and user conduct. This helps to check the level at which users violate library regulations as well as educate patrons on the use of libraries. On the importance of user education in relation to promoting observance, the result of Afolabi (2005) [6] study shows that most students who attended library orientation do not engage in infraction of library rules and regulations when compared with their counterparts who did not participate in the orientation programme.

According to Mason (2010) [7], an academic library has the mission to build and maintain a collection that will support and enhance the instructional needs of the institution. He also supported other researchers that academic library is to provide access to all sources of information. Mason (2010) [8] acknowledges that information resources are not always available in the right quantity desired even for institutions in the Western World where publications output is very high. In this regard, Africa particularly suffers a problem scholars have tagged "book famine".

Abosede and Ibikunle (2011) [9] are of the view that the positive impression of the staff's response to students is of importance in encouraging library use and observance of library regulations. The staff's response to students' needs must be constantly re-evaluated and will help the library management in encouraging students' use of the library and their observance of library regulations.

The length of time that libraries open determines the usage of the library resources and thus indirectly determines the degree of observance of library regulations. Edoka (2000) [10] carried out a study in which he observed that convenient hours are crucial factors in making library policy observable. The result of his study shows that users agree to the fact that library opening hours should be extended at weekdays and be opened during the weekends.

Libraries charge fines for materials that are lost, mutilated, stolen and kept beyond due dates. These fines are meant not only to generate monies for libraries but also to serve as deterrent for users who take library rules for granted. Nwalo (2003) [11] states that in the light of the present inflation rate in Nigeria, defaulters should be made to pay high levies. In contrast, Udoh (2004) [12] asserts that when fine is too much, it will serve as a further deterrent to students from returning library books.

To promote the air of calm, efficiency and confidence in the library which anti-library users find unsettling, Adio (2009) [13] is of the view that there must be good security within the library. Such include establishing identity for staff and users, good key discipline, unobstructive bag search, challenging strangers and unauthorized entrants in a non-provocative manner, lock in restricted/closed areas, individual staff member responsible for the equipment and other library resources in their charge and high level of staff presence.

In libraries, students are expected to observe the regulations. Library regulations have helped to maintain the resources and services provided in the library. In other words, library regulations are integral part of library activities.

\section{Methodology}

The survey design was used to conduct this study. The population consisted of the 400 registered users in the library of Federal Polytechnic Nekede, Owerri. A sample of 196 was used for the study (this was guided by Krejcie and Morgan (1970) [14] table of determining sample size). The questionnaire was the major research instrument for collecting data. It was structured using the four-point scale which was rated as follows: Strongly Agree $=4$, Agree $=3$, Disagree $=2$ and Strongly Disagree $=1$. The research instrument was developed by the researcher based on the research questions. The data collected were analysed using mean rating scale at 2.50 cut-off point.

\section{Presentation of Findings}

Out of the 196 copies of questionnaire distributed, 187 were returned showing a 95\% return rate.

Research Question I: What is the influence of user education on students' observance of library regulations?

Table 1 reveals that all the items except question item 3, obtained mean rating above 2.50. This is an indication that those items are generally accepted as influencing factors to students' observance of library regulations as it relates to user education as a determinant. Hence user education is a strong determinant of students' observance of library regulations, so has an influence. This is in agreement with the result of the study conducted by Afolabi (2005) [6] which shows that most students who attended library orientation did not engage in infrac- 
tion of library rules and regulations. However, majority of the students do not have the Library Guide where the regulations are published.

Research Question II: What is the influence of availability of information resources on Students' observance of library regulations?

In Table 2, the mean ratings for items 8 and 9 were below the acceptance level of 2.50. This means that the respondents did not agree that they have influence on observance of library regulations though they accepted that there are few copies of some books that are heavily used as can be seen with its 2.89 mean rating and they violate library regulations if information resources cannot be borrowed. This is in agreement with Ibenne (2010) [8] who reports that information resources are not always available in the right quantity desired even for institutions in the Western World where publications output is very high. In this regards, Africa particularly suffers a problem scholars have referred to as "book famine".

Research Question III: What is the influence of staff attitudes on Students' observance of library regulations?

Mean rating of staff's attitude in Table 3 reveals that all the items obtained mean rating above 2.50 . This is an indication that all the listed items are generally accepted as influencing factors on their observance of library regulations. This shows that staff's attitude go a long way in determining students' observance of library regulations. This is in tandem with Abosede and Ibikunle (2011) [9] study that observed that the positive impression of the staff's response to students is of importance in encouraging library use and observances of library regulations.

Research Question IV: What is the influence of operating hours on Students' observance of library regulations?

Table 4 indicates that all the items obtained mean rating below 2.50. This shows that the respondents did not accept them as determining factors of their observance. It can therefore be deduced that operating hours of the library is not a major determinant of students' observance of library regulations. This finding does not agree with Aguolu and Aguolu (2002) [3] observation that typical library hours are unsatisfactory because libraries are heavily used at evening and weekends by students thus causing users not to observe policies.

Research Question V: What is the influence of disciplinary measures on students' observance of library regulations?

Apart from item 19 which obtained a mean rating below 2.50, the rest of the items have mean rating above 2.50 indicating that they are generally accepted as disciplinary measures used to encourage observance of library regulations. Hence, disciplinary measures put in place by libraries influence students' observance of library regulations with exception of overdue date. This may be due to the small amount collected as overdue fine (5 naira per day). This is why Nwalo (2003) [11] states that defaulters should be made to pay high levies (Table 5).

Research Question VI: What is the influence of security measures on students' observance of library regulations?

In Table 6, items 24 - 27 have mean rating above 2.50 and are accepted as security measures that discourage students from non-observance of library regulations. This finding supports that of Adio (2009) [13] who is of the view that there must be good security within the library to promote the air of calm, efficiency and confidence in the library which anti-library users find unsettling.

Table 1. Mean rating of user education and students' observance of library regulations.

\begin{tabular}{|c|c|c|c|c|}
\hline $\mathbf{S} / \mathbf{n}$ & Questionnaire Items & $\begin{array}{l}\text { Number of } \\
\text { Response }\end{array}$ & Mean (x) & Remarks \\
\hline 1. & I am aware of the existence of library regulations. & 178 & 3.06 & Positive \\
\hline 2. & Library regulations are adequately taught in user education course. & 184 & 2.89 & Positive \\
\hline 3. & $\begin{array}{c}\text { A copy of the Library Guide where the library regulations are published is } \\
\text { given to every student. }\end{array}$ & 160 & 2.03 & Negative \\
\hline 4. & User education course is compulsory for all students in my school. & 183 & 2.72 & Positive \\
\hline 5. & $\begin{array}{l}\text { The time used to teach user education is adequate for students to be aware } \\
\text { of library regulations. }\end{array}$ & 179 & 2.72 & Positive \\
\hline 6. & I observe library regulations because I attended user education course. & 183 & 2.72 & Positive \\
\hline
\end{tabular}


Table 2. Mean rating of availability of information resources and students' observance of library regulations.

\begin{tabular}{|c|c|c|c|c|}
\hline $\mathbf{S} / \mathbf{n}$ & Questionnaire Items & Number of Response & Mean (x) & Remarks \\
\hline 7. & There are few copies of some books that are heavily used. & 179 & 2.89 & Positive \\
\hline 8. & $\begin{array}{l}\text { Library regulations restricting students' access to certain collections } \\
\text { make me to violate such regulation. }\end{array}$ & 180 & 2.14 & Negative \\
\hline 9. & I sometimes remove pages from library books. & 185 & 2.00 & Negative \\
\hline 10. & $\begin{array}{l}\text { I violate library regulations if the information resource } \\
\text { cannot be borrowed. }\end{array}$ & 182 & 2.79 & Positive \\
\hline
\end{tabular}

Table 3. Mean rating of staff attitudes and students’ observance of library regulations.

\begin{tabular}{|c|c|c|c|c|}
\hline $\mathbf{S} / \mathbf{n}$ & Questionnaire Items & $\begin{array}{l}\text { Number of } \\
\text { Response }\end{array}$ & Mean (x) & Remarks \\
\hline 11. & Library staff report offenders to the authorities for disciplinary action. & 184 & 2.87 & Positive \\
\hline 12. & Library staffs control the behavior of students when using the library. & 187 & 3.03 & Positive \\
\hline 13. & Library staffs do not allow students to sleep in the library. & 184 & 2.82 & Positive \\
\hline 14. & $\begin{array}{l}\text { Library staffs help me in my search for information which makes } \\
\text { me to observe library regulations. }\end{array}$ & 181 & 3.13 & Positive \\
\hline
\end{tabular}

Table 4. Mean rating of operating hours and students’ observance of library regulations.

\begin{tabular}{|c|c|c|c|c|}
\hline $\mathbf{S} / \mathbf{n}$ & Questionnaire items & $\begin{array}{l}\text { Number of } \\
\text { Response }\end{array}$ & Mean (x) & Remarks \\
\hline 15. & Insufficient library hours discourage me from observing library regulations. & 185 & 1.91 & Negative \\
\hline 16. & I do not observe library regulations at night. & 174 & 1.71 & Negative \\
\hline 17. & I do not observe library regulations at weekends. & 160 & 2.03 & Negative \\
\hline 18. & Staying longer in the library makes me to eat there. & 185 & 1.93 & Negative \\
\hline
\end{tabular}

Table 5. Mean rating of disciplinary measures and students’ observance of library regulations.

\begin{tabular}{|c|c|c|c|c|}
\hline $\mathbf{S} / \mathbf{n}$ & Questionnaire Items & $\begin{array}{l}\text { Number of } \\
\text { Response }\end{array}$ & Mean (x) & Remarks \\
\hline 19. & 0verdue fine discourages me form exceeding the overdue date. & 172 & 2.26 & Negative \\
\hline 20. & $\begin{array}{l}\text { Students who violate library regulations are made } \\
\text { to face the students' disciplinary panel. }\end{array}$ & 187 & 2.98 & Positive \\
\hline 21. & Students who exceed overdue date pay overdue fine. & 179 & 3.09 & Positive \\
\hline 22. & $\begin{array}{l}\text { Fear of being handed over to the students' disciplinary panel } \\
\text { discourages me from violating library regulations. }\end{array}$ & 186 & 2.91 & Positive \\
\hline 23. & $\begin{array}{l}\text { Violation of library regulations may lead to } \\
\text { withdrawal of my library card. }\end{array}$ & 180 & 3.19 & Positive \\
\hline
\end{tabular}

Table 6. Mean rating of security measures and students’ observance of library regulations.

\begin{tabular}{|c|c|c|c|c|}
\hline $\mathbf{S} / \mathbf{n}$ & Questionnaire Items & Number of Response & Mean (x) & Remarks \\
\hline 24. & $\begin{array}{l}\text { Porters at the exit door prevent students from stealing } \\
\text { library resources. }\end{array}$ & 183 & 3.16 & Positive \\
\hline 25. & $\begin{array}{l}\text { Students show their identity cards before being } \\
\text { allowed to enter the library. }\end{array}$ & 187 & 3.48 & Positive \\
\hline 26. & Use of ownership stamp prevents students from stealing library books. & 187 & 3.08 & Positive \\
\hline 27. & $\begin{array}{l}\text { Staff surveillance of reading rooms encourages } \\
\text { me to observe library regulations. }\end{array}$ & 183 & 3.08 & Positive \\
\hline
\end{tabular}




\section{Conclusion}

Having carried out this research on "Determinants of students' observance of library regulations” with particular regards to library-related factors, the findings show that all the determinants have influence on students' observance of library regulations with the exception of operating hours and questionnaire items on overdue fine, regulation restricting students access and mutilation. This is so because all the questionnaire items with regards to them obtained a mean rating below 2.50 .

\section{Recommendations}

Based on the findings of the study, the following recommendations are made:

1) User education should be intensified since it exposes students to library regulations and encourages them to observe them.

2) All the students should be given a copy of the Library Guide during their registration.

3) There should be acquisition of more copies of heavily used information resources.

4) The efforts of the staff in ensuring observance should be encouraged.

5) Overdue fine should be increased to discourage students form keeping library resources beyond the due date.

6) Disciplinary measures adopted by the library under study should be continued with and adhered to strictly.

7) The security measures used should be maintained and other measures such as electronic monitor added.

\section{References}

[1] Alokun, N.A. (2004) The Use of Library: A Textbook for Students in Tertiary Institutions. Nudex International Co. Ltd., Lagos.

[2] Whitemire, E. (2001) The Influence between Undergraduates’ Background Characteristics and College Experiences and Their Academic Library use. College and Research Libraries. http://www.crl.acrl.org/content/6216/528.full.pdf

[3] Aguolu, C.C. and Aguolu, I.E. (2002) Libraries and Information Management in Nigeria: Seminal Essays on Themes and Problems. Ed-Linform Services, Maiduguri.

[4] Broadhead, R.M (2002) Theft in Academic Libraries. In: Ebunuwele, G.E., Yaya, J. and Krubu, D.E., Eds., User Delinquency in Nigerian Academic Libraries: An Empirical Perspective. Library Philosophy and Practice (e-Journal). http://digitalcommons.unl.edu/libphilprac/558

[5] Nina-Okpousung, M.O. (2011) Library Policies and Overdue Materials in Delta State Polytechnic Library, Nigeria. Journal of Research in Education and Society, 2, 199-207.

[6] Afolabi, K.A. (2005) Impact of Library Orientation Programme on the Use of Library Resources by Students of Adeyemi College of Education Ondo, Nigeria. Gateway Library Journal, 11, 46-54.

[7] Mason, M.K. (2010) Myths Associated with Undergraduate Use of Academic Libraries. http://www.mayok.om.papers/anxiety.html

[8] Ibenne, S.K. (2010) Information Resources Management: A Concise Text for Libraries and Information Centres. Liu House, Owerri.

[9] Abosede, A.T. and Ibikunle, O.O. (2011) Determinants of Library Use among Students of Agriculture: A Case Study of Lagos State Polytechnic. Library Philosophy and Practice, 521. http://digitalcommons.unl.edu/libphilprac/521

[10] Edoka, B.E. (2000) Introduction to Library Science. Palma and Links Company, Onitsha.

[11] Nwalo, K.N. (2003) Fundamentals of Library Practice: A Manual on Library Routines. Stirling-Horden Publishers, Lagos.

[12] Udoh, O.O. (2004) Concept of the Library. In: Duru, E.C. and Okon, M.C., Eds., Information Use in Tertiary Institutions in Nigeria, Abaam Publishing Coy, Uyo.

[13] Adio, A.F. (2009) Management of Anti-Library Use Behavior in Nigerian Libraries. Nigerbiblios, 20, 43-51.

[14] Krejcie, R.V. and Morgan, D.W. (1970) Determining Sample Size for Research Activities. Educational and Psychological Measurement, 30, 607-610. 